\title{
Stewige skelet van poësie
}

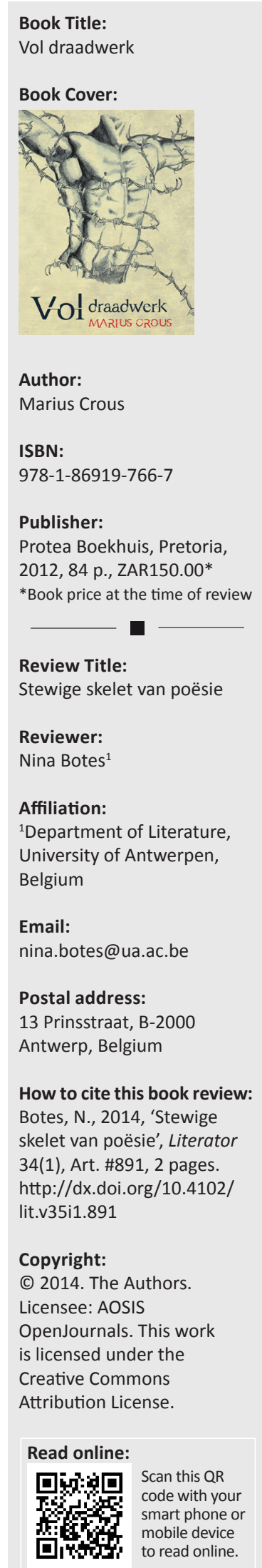

Vol draadwerk, Crous se derde digbundel, is 'n hoogtepunt in sy oeuvre tot dusver. Hierdie bundel bou voort op temas en tegnieke wat reeds in Brief uit die kolonies (2003) en Aan 'n beentjie sit en kluif (2006) opgeval het, soos die digte verwysingsraamwerk, intellektuele inslag en fassinasie met liggaamlikheid (veral dood en homoërotiese seks). Al die verse is nie ewe geslaagd nie, maar die beste gedigte getuig van 'n bedrewenheid wat die leser imponeer.

Teoretiese tekste, veral uit die psigoanalise, vorm 'n belangrike sleutel tot die teks, soos aangedui deur die motto's uit Freud en Kristeva se skool van denke. Die eerste afdeling heet gepas 'Chora' en situeer die eerste gedigte binne die semiotiese proses waarbinne die taal/betekenisdichotomie wat die simboliese orde kenmerk, opgehef word. Die semiotiese, synde deel van die pre-Oedipale, word met die moeder se liggaam geassosieer. Die semiotiese is gekoppel aan die materiële aspekte van taal soos toon en ritme, maar ook aan ontwrigting, stilte en afwesigheid: 'unnameable, improbable, hybrid, anterior to naming, to the One, to the father.' [... onnoembaar, onwaarskynlik, hibridies, voor naamgewing, aan die Een, aan die vader.] Kristeva trek dan ook 'n verband tussen die semiotiese en poëtiese taal.

Afdeling een is binne hierdie konteks 'n psigoanalitiese besinning oor die wyses waarop die kunstenaar inspirasie uit die onbewuste put, met verwysings na musiek (Debussy, Mahler), skilderkuns (Dumas) en poësie (Ruth Fainlight en William Blake). In die openingsgedig, 'Gesonke katedraal', aktiveer Crous hierdie semiotiese proses wanneer die simbole in die katedraal ontheg word van hul betekenis om in die moederlike aspek van taal die kreatiewe impuls te ontsluit: die kruis 'wieg soos seebamboes / losgehaak tussen die dobberende mariabeelde'. Hierdie gedig vorm 'n eenheid met 'Duiker by Ys-eiland' en 'Messiaen', terwyl die kreatiewe verder ondersoek word in die treffende 'Songs of innocence' en 'Songs of experience'.

Die psigoanalise bied ook 'n sleutel tot afdeling vyf, waarin daar gefokus word op verskillende tipes vaderfigure. Meestal word die vader as simbool van die patriargie onomwonde genegeer, soos in die uitmuntende 'Vaderland 1' en 'Vaderland 2'. In laasgenoemde word hierdie aspek byvoorbeeld in verband gebring met die geweld in Suid-Afrika:

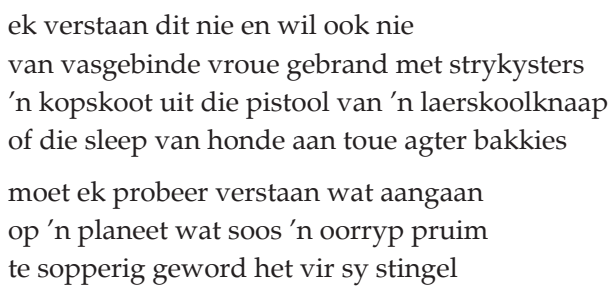

Van die gedigte in hierdie afdeling verwys ook na die religieuse, veral georganiseerde godsdiens se onvermoë om die kompleksiteite van bestaan bevredigend te omvat. In 'Teologie' word die vader in verband gebring met die popkultuur, en word geloof ' $n$ verwarrende, hol simbool. Dit is ook in hierdie gedig wat die eerste verwysing na die titel aangetref word: 'met god die darth vader / jesus die skywalker / die geloof 'n draadwerk matryse'. In 'Meditasie' verwys die bundeltitel weer na 'die hart se draadwerk' en die wyses waarop 'n mens die bestaan deur godsdiens kan ken.

Nog 'n weergawe van die vader word aangetref in 'Metateks', wat een van die hoogtepunte van hierdie afdeling is. Hier gaan dit oor die wyses waarop die digter afreken met die literêre vader en:
uitwerk teen watter hoek
hulle hom moet bespring
met'n klip moet kap moet oopsny
of hom finaal van sy rotspunt afstoot
sy laaste kreet in jambes opdeel
en in die vallei gaan verkwansel

Literêre voorgangers is ook die fokus in die tweede afdeling waarin antieke tekste uit die Griekse en Romeinse kanon opgehaal word. Hierdie afdeling is die swakste in die bundel omdat 
dit te veel in die bekende gegewe vassteek sonder om 'n noemenswaardige eie perspektief te bied. Wanneer Crous die mitologie gebruik om 'n ander onderwerp te belig, slaag hy wel besonder goed, soos in 'Gaea' en die homoërotiese 'Empedokles'. In die vierde afdeling word die gesprek voortgesit met gedigte oor bekende figure, en veral 'Helen Martins' en 'Angela Carter' is gedigte wat jou bybly.

Met die gedigte oor Port Elizabeth sluit Crous ook aan by die tendens van sogenaamde stadspoësie. Verse soos 'Vanstadensrivier', 'Campanile' en 'Schoenmakerskop' steek nie bloot vas in beskrywings of oppervlakkige belewenisse van die ruimte nie, maar word funksioneel aangewend om 'n spesifieke werklikheid vas te vang.

Die laaste afdeling handel veral oor die homoërotiek en sluit aan by Crous se tweede bundel, Aan ' $n$ beentjie sit en kluif
(2006). In 'Wawielstraat' word die voormalige glansryke bestaan van die digter-akademikus gekontrasteer met 'n voorstedelike lewe in 'n Wendyhuis met die Huisgenoot as bron van kennis. Hoewel enkele van die gedigte in hierdie afdeling maar bra middelmatig is, vergoed gedigte soos die onthutsende 'Reis' met sy knalslot, 'Evolusie' en 'Susterlike gesprekke met Margery Kempe' deur en deur hiervoor.

Die intertekstuele verband met draadwerk maak dat $V o l$ draadwerk nie 'n baie toeganklike bundel is nie en Crous kan seker nie ' $n$ wye gehoor verwag nie. Tog is dit ' $n$ bundel met puik gedigte wat 'n lonende leeservaring bied.

\section{Literatuurverwysings}

Crous, M., 2003, Brief uit die kolonies, Protea Boekhuis, Pretoria.

Crous, M., 2006, Aan 'n beentjie sit en kluif, Protea Boekhuis, Pretoria. 